\title{
BINDING OF CORTICOSTEROIDS BY PLASMA PROTEINS. I. DIALYSIS EQUILIBRIUM AND RENAL CLEARANCE STUDIES 1, 2
}

\author{
By WILLIAM H. DAUGHADAY, with THE technical ASSISTANCE of RITA BREMER \\ AND CAROLYN HARTNETT COLLINS
}

\author{
(From the Department of Internal Medicine, Washington University School of Medicine, \\ St. Louis, Missouri)
}

(Submitted for publication August 2, 1956; accepted September 5, 1956)

Many biologically significant substances circulate in the plasma bound to plasma proteins to a variable extent. This phenomenon is particularly evident in the plasma transport of certain hormones. The high degree of binding of thyroxine by an alpha globulin is well known. Estrogens, too, have been recognized to have a high affinity for plasma proteins. Bischoff and Katherman (2) observed that estrone was more than 100 times more soluble in human serum than in neutral buffers, a finding indicative of protein binding. A systematic study of the solubilities of certain steroids in bovine serum albumin has been made by Eik-Nes, Schellman, Lumry and Samuels (3). Of the steroids tested, estradiol, $\Delta 4$ androstene-3one, and androstane-17-one were most tightly bound to bovine albumin serum on the basis of solubility studies. These compounds proved to be more than 400 times more soluble in 5 per cent albumin than in neutral buffers. The affinity of cortisone for albumin was considerably less, and this steroid was only two to three times more soluble in 5 per cent albumin solutions than in buffer. The other steroids of biologic interest exhibited intermediate affinity for albumin. The strength of the steroid protein-union decreased as the number of polar groups of the steroid increased.

Additional observations on the binding of testosterone by bovine serum albumin have been made by Schellman, Lumry and Samuels (4) using dialysis equilibrium and solvent partition analysis in a two-phase system. A linear relation between the reciprocal of the average number of mole-

\footnotetext{
1 Reported in part at the Annual Meeting of the American Society of Biological Chemists, April, 1956 (1).

2 This investigation was supported by a research grant, C-255 (C3), from the National Institute of Arthritis and Metabolic Diseases, of the National Institutes of Health, Public Health Service.
}

cules of steroid bound per protein molecule and the reciprocal of the substrate concentration was observed. Differences in the binding affinity of three samples of bovine albumin were attributed to differences in the purity of the proteins. The binding of testosterone increased with temperature and $\mathrm{pH}$, and was inhibited in the presence of thiocyanate ion, methyl orange and zinc.

In this paper the results of dialysis equilibrium experiments with plasma from normal subjects receiving cortisone are presented. The binding affinities of isolated human plasma protein fractions for hydrocortisone are described, and the renal clearance of $17-\mathrm{OH}$ corticosteroids and their glucuronides is interpreted in terms of the physical state of these substances in plasma.

\section{METHODS}

Normal adult male volunteers were permitted a lowfat breakfast. Adequate urine flow was achieved by water loading and urine was collected by voiding in thirtyminute periods. Heparinized blood was obtained at the mid-point of the urine collection period. In certain experiments cortisone acetate ( $75 \mathrm{mg}$. by mouth) was given after the measurement of endogenous corticosteroid clearances and two hours prior to the collection of urine, for measuring the clearance after loading. Heparinized plasma obtained at the mid-point of this collection was used both to determine renal clearance and also for measurement of binding by dialysis equilibrium. The clearances were repeated in 5 subjects several days later after the ingestion of 2.0 to $2.5 \mathrm{gm}$. of probenecid.

The binding of $17-\mathrm{OH}$ corticosteroids (17-OHCS) and 17-OH corticosteroid glucuronides (17-OHCS-Gluc) by plasma proteins was determined by dialysis equilibrium in the following manner. One volume of plasma, usually $20 \mathrm{ml}$., was placed in a Visking cellophane tube (Nojax 18/32 Casing) containing 6 to 10 glass beads. The cellophane bag was placed in a large test tube containing four volumes of Krebs phosphosaline buffer (5). This buffer has a pH of 7.4, an ionic strength of 0.139 and contains the following ions expressed as milliequivalents per liter: $\mathrm{Na} 158, \mathrm{~K} 4.6, \mathrm{Mg} 4.6, \mathrm{Cl} 123, \mathrm{SO}$ ، 4.6, 
$\left(\mathrm{HPO}_{4}+\mathrm{H}_{2} \mathrm{PO}_{4}\right)$ 40. The tube was sealed and rotated on a disk 12 times a minute at $4^{\circ} \mathrm{C}$ for 48 hours. The contents of the bag and the outside dialysis buffer were analyzed for 17-OHCS and 17-OHCS-Gluc. The protein content within the bag was determined by the Weichselbaum modification of the biuret reaction (6).

The method of Nelson and Samuels (7) for plasma corticosteroids has been modified in these studies. Plasma proteins were precipitated with four volumes of acetone and removed by filtration. Fats were removed by partitioning between Skelly Solve B and 80 per cent aqueous acetone. After removal of acetone under reduced pressure, the aqueous phase was extracted with $50 \mathrm{ml}$. of ethyl acetate three times. Fifteen milliliters of water was used to back-extract the ethyl acetate extract before evaporation to a residue under reduced pressure at $40^{\circ} \mathrm{C}$.

17-OHCS-Gluc were determined on the pooled aqueous phases after hydrolysis with bacterial $\beta$-glucuronidase (Sigma). Several schedules of addition of enzyme have been investigated to achieve maximum hydrolysis of the glucuronide conjugates. The method selected for use in these studies employed the addition of 800 units of enzyme at two-hour intervals three times, followed by incubation overnight. The liberated steroids were then extracted and the same hydrolysis was repeated on a second day and again extracted with ethyl acetate. The need for such an elaborate scheme of hydrolysis was indicated by analysis of the first and second days' extracts separately. The Porter-Silber chromogen on the second day yielded an additional 20 to 50 per cent.

17-OHCS and 17-OHCS-Gluc were determined in urine and in the dialysate in the equilibrium experiments under the same conditions used for plasma, except that deproteinization and delipidization were not carried out.

Florisil chromatography was performed according to Nelson and Samuels (7) to reduce the nonspecific PorterSilber chromogens. After suitable corrections for reagent chromogens, sulfuric acid chromogens and the losses of $17-\mathrm{OH}$ corticosteroids on the columns, the concentrations of 17-OHCS and 17-OHCS-Gluc were calculated and expressed in terms of hydrocortisone.

In some clearance experiments urinary 17-OHCS and 17-OHCS-Gluc were measured also by the method of Silber and Porter (8) using 800 units of bacterial beta glucuronidase for $2 \mathrm{ml}$. of urine and incubating for 24 hours to determine the combined free and glucuronide 17-OHCS.

The human plasma protein fractions (Cohn) were obtained from Dr. J. Newton Ashworth of the American Red Cross. Four per cent protein solutions by weight were prepared and insoluble material was removed by centrifugation. Cellophane bags containing $10 \mathrm{ml}$. of protein solution were dialyzed against $40 \mathrm{ml}$. of phosphosaline buffer to which hydrocortisone had been added in dilute alcoholic solution. The final alcohol concentration was 3 per cent at the highest steroid concentrations tested. After 24 hours of dialysis the hydrocortisone in the bag and in the dialysate was measured by the method of Silber and Porter (8). A slight reaction with phenylhydrazine reagent was observed with extracts from albumin solutions to which no hydrocortisone had been added. In experiments with low concentrations of added hydrocortisone, this chromogen of doubtful specificity was subtracted from that obtained in the presence of hydrocortisone. The addition of hydrocortisone to the protein solution rather than to the external buffer resulted in the same steroid distribution, indicating that equilibrium had been closely approached with this period of dialysis.

Creatinine was determined in plasma and urine by a spectrophotometric modification of the method of Folin and $\mathrm{Wu}$ (9).

\section{RESULTS}

The degree of binding of the plasma 17-OHCS and 17-OHCS-Gluc as indicated by dialysis equilibrium measurements has been summarized in Table I. The concentration of the non-protein bound moiety of the two types of steroids per 100 $\mathrm{ml}$. of water within the dialysis bag has been calculated from the concentration of the steroid outside the bag and the protein concentration within the bag. The concentration of the protein bound $17-\mathrm{OHCS}$ and 17-OHCS-Gluc within the bag is the difference between the total amount of the respective steroids measured within the bag less the calculated free steroid concentration. Under the experimental conditions employed, 94 per cent of the 17-OHCS present within the dialysis bag was bound to the plasma proteins. Although conjugation of 17-OHCS to glucuronides substantially reduced the degree of binding by protein, about two thirds remained associated with the protein components of the system.

The identity of the plasma proteins which are responsible for binding corticosteroids has been investigated by performing dialysis equilibrium stud-

TABLE I

Binding of corticosteroids by plasma proteins *

\begin{tabular}{|c|c|c|c|c|c|}
\hline \multirow[b]{2}{*}{ Expt. } & & \multicolumn{2}{|c|}{$\begin{array}{l}17 \text { OHCS } \\
\mu g . / 100 \mathrm{ml} .\end{array}$} & \multicolumn{2}{|c|}{$\begin{array}{c}17 \text { OHCS-Glucuronide } \\
\mu 8 . / 100 \mathrm{ml} .\end{array}$} \\
\hline & & Free & Bound & Free & Bound \\
\hline \multirow[t]{2}{*}{$\begin{array}{l}1 \\
2 \\
3 \\
4 \\
5\end{array}$} & & $\begin{array}{l}2.06 \\
0.93 \\
2.12 \\
1.49 \\
2.63\end{array}$ & $\begin{array}{l}29.2 \\
29.1 \\
39.3 \\
26.2 \\
30.3\end{array}$ & $\begin{array}{c}5.15 \\
7.46 \\
10.0 \\
13.3 \\
14.0\end{array}$ & $\begin{array}{l}12.4 \\
15.5 \\
17.5 \\
29.0 \\
18.1\end{array}$ \\
\hline & $\begin{array}{l}\text { Mean } \\
\%\end{array}$ & $\begin{array}{l}1.85 \\
5.7\end{array}$ & $\begin{array}{l}30.8 \\
94.3\end{array}$ & $\begin{array}{l}10.0 \\
35.2\end{array}$ & $\begin{array}{l}18.5 \\
64.8\end{array}$ \\
\hline
\end{tabular}

* Dialysis equilibrium: plasma from normal subjects $2 \mathrm{hrs}$. after $75 \mathrm{mg}$. oral cortisone acetate dialyzed against phosphosaline buffer pH $\mathbf{7 . 4}$. 
TABLE II

Binding of hydrocortisone by plasma protein fractions *

\begin{tabular}{|c|c|c|c|}
\hline \multirow[b]{2}{*}{$\begin{array}{c}\text { Fractions } \\
\text { (Cohn) }\end{array}$} & \multirow[b]{2}{*}{$\begin{array}{c}\text { Protein } \\
m g . / m b\end{array}$} & \multicolumn{2}{|c|}{ Hydrocortisone } \\
\hline & & $\begin{array}{c}\text { Free } \\
\mu \mathrm{s} . / \mathrm{ml} \text {. }\end{array}$ & $\begin{array}{l}\text { Bound } \\
\text { Mg. } / \mathrm{ml} \text {. }\end{array}$ \\
\hline $\begin{array}{l}\text { I } \\
\text { II } \\
\text { III } \\
\text { IV-1 } \\
\text { IV-4 } \\
\text { V }\end{array}$ & $\begin{array}{l}30 \\
29 \\
19 \\
17 \\
29 \\
30\end{array}$ & $\begin{array}{r}123 \\
113 \\
115 \\
113 \\
103 \\
95\end{array}$ & $\begin{array}{r}12 \\
24 \\
20 \\
1 \\
74 \\
110\end{array}$ \\
\hline
\end{tabular}

* Dialysis equilibrium: human plasma protein fractions and hydrocortisone.

ies using plasma protein fractions prepared by the Cohn method. From the results listed in Table II, the greatest binding activity is evident in the albumin fraction (Fraction V). The affinity of Fraction IV-4 can be ascribed to the albumin content of this fraction. The affinity of the proteins for steroids at this relatively high steroid concentration is less than observed in human plasma. The influence of steroid concentration on the binding of hydrocortisone by human Fraction $\mathrm{V}$ and by bovine plasma albumin is illustrated in Figure 1. To compare the affinity of hydrocortisone for albumin the expression $r /[S]=K(n-r)$ has been employed by Eik-Nes, Schellman, Lumry, and Samuels (3). [S] is the molar concentration of unbound steroid and $r$ is the average number of substrate molecules bound per molecule of protein. $K$ is the intrinsic association constant for the binding sites, and $\mathrm{n}$ is a function of the binding sites per protein molecule. Under the conditions employed in this study where the value of $r$ is small, $r /[S]$ provides an indication of the magnitude of $\mathrm{K}$ for comparative purposes. At steroid concentration of $60 \mu \mathrm{M}$ per liter, and higher, the affinity was found to be similar to that reported (3). At lower concentrations where the value of $r$ was only a small fraction of the albumin molecules, there was a rise in the value of $r /[S] \times$ $10^{-4}$. A similar affinity at low hydrocortisone concentration was observed in four other human Fraction $\mathrm{V}$ preparations obtained from American Red Cross. One of these human Fraction V preparations did not contain added caprylate.

The process of glomerular filtration represents a physiologic ultrafiltration. It is of interest, therefore, to correlate the in vitro dialysis equilibrium experiments which have been carried out with the clearance of 17-OHCS and 17-OHCSGluc. The measured clearances of endogenous creatinine, 17-OHCS and 17-OHCS-Gluc are listed in Table III. Although the clearance of $17-\mathrm{OHCS}$ is consistently low, in keeping with the findings of other workers, we have found the clearance of the 17-OHCS-Gluc to be higher in some individuals than that previously reported $(10,11)$. The variability of the $17-\mathrm{OHCS}-$ Gluc, except in the subject $E$. J., could not be attributed to obvious analytic errors. Performance of the urinary $17-\mathrm{OHCS}-$ Gluc by two different methods in the last three studies tabulated did not alter the clearances materially. Figure 2 presents the ratios of steroid to creatinine clearance for both the conjugated and unconjugated 17-OHCS, under the four experimental conditions studied. The lower marking tab to the right of the columns indicates the clearance of $17-\mathrm{OHCS}$ predicted on the basis of the dialysis equilibrium experiments assuming that glomerular filtration is the only renal excretory mechanism. The agreement between predicted and observed clearances supports this concept. In the case of the 17-OHCS-Gluc the predicted clearance (upper marking tab) proved to be lower than the observed clearances in the ab-

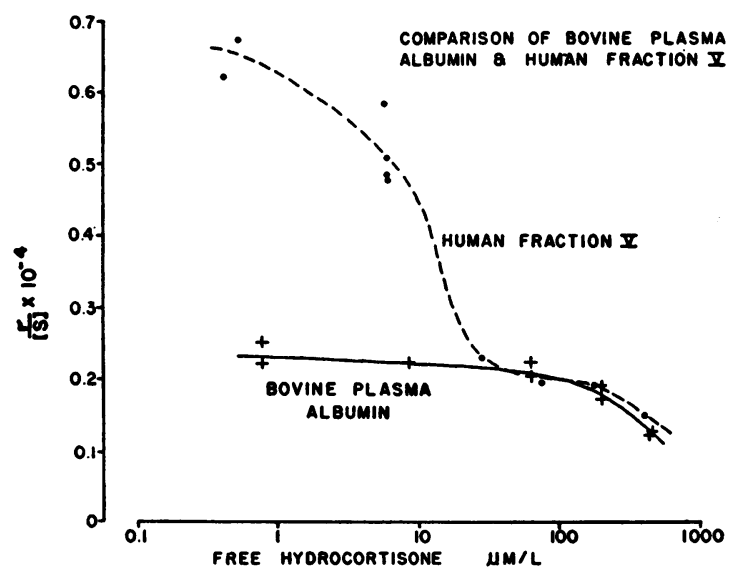

Fig. 1. The Afrinity of Human and Bovine Albumin for Hydrocortisone at Different Steroid Concentrations

The albumin solutions were made up to be 4 per cent by weight in phosphosaline buffer. The free hydrocortisone concentration was the concentration of steroid within the bag not in combination with protein. The affinity of albumin for hydrocortisone has been plotted on the ordinate as $r /[\mathrm{S}] \times 10^{-4}$. The use of this expression is described in the text. 
TABLE III

The Clearance of 17-OHCS and 17-OHCS-Glucuronides

\begin{tabular}{|c|c|c|c|c|c|}
\hline Subject & $\begin{array}{l}\text { Cortisone } \\
\text { Loading }\end{array}$ & Benemid & $\begin{array}{l}\text { Creatinine } \\
\text { Clearance } \mathrm{ml} / \mathrm{min}\end{array}$ & $\begin{array}{l}\text { 17-OHCS } \\
\text { Clearance } \mathrm{ml} / \mathrm{min}\end{array}$ & $\begin{array}{l}\text { 17-OHCS-Gluc } \\
\text { Cloarance } \mathrm{ml} / \mathrm{min}\end{array}$ \\
\hline W.D. & $\begin{array}{l}0 \\
+ \\
0 \\
+\end{array}$ & $\begin{array}{l}0 \\
0 \\
+ \\
+\end{array}$ & $\begin{array}{l}119 \\
115 \\
102 \\
100\end{array}$ & $\begin{array}{r}3.5 \\
12.0 \\
15.6 \\
7.1\end{array}$ & $\begin{array}{r}175 \\
156 \\
69 \\
60\end{array}$ \\
\hline E. J. & $\begin{array}{l}0 \\
+ \\
0 \\
+\end{array}$ & $\begin{array}{l}0 \\
0 \\
+ \\
+\end{array}$ & $\begin{array}{l}147 \\
117 \\
112 \\
106\end{array}$ & $\begin{array}{r}7.9 \\
10.9 \\
7.2 \\
14.9\end{array}$ & $\begin{array}{r}51 \\
51 \\
100 \\
80\end{array}$ \\
\hline $\mathbf{W} \cdot \mathbf{M}$ & $\begin{array}{l}0 \\
+ \\
0 \\
+\end{array}$ & $\begin{array}{l}0 \\
0 \\
+ \\
+\end{array}$ & $\begin{array}{l}126 \\
148 \\
118 \\
128\end{array}$ & $\begin{array}{l}2.9 \\
3.4 \\
3.0 \\
2.4\end{array}$ & $\begin{array}{r}179 \\
192 \\
28 \\
62\end{array}$ \\
\hline M. L. & $\begin{array}{l}0 \\
+ \\
0 \\
+\end{array}$ & $\begin{array}{l}0 \\
0 \\
+ \\
+\end{array}$ & $\begin{array}{r}112 \\
91 \\
95 \\
115\end{array}$ & $\begin{array}{l}9.7 \\
7.6 \\
9.0 \\
8.6\end{array}$ & $\begin{array}{l}85 \\
74 \\
51 \\
47\end{array}$ \\
\hline s.G. & $\begin{array}{l}0 \\
+ \\
0 \\
+\end{array}$ & $\begin{array}{l}0 \\
0 \\
+ \\
+\end{array}$ & $\begin{array}{r}125 \\
99 \\
105 \\
106\end{array}$ & $\begin{array}{l}8.0 \\
8.0 \\
3.2 \\
8.0\end{array}$ & $\begin{array}{l}76 \\
82 \\
57 \\
43\end{array}$ \\
\hline J.M. & + & 0 & 122 & $\begin{array}{l}15.4 \\
(12.9) *\end{array}$ & $\begin{array}{l}182 \\
(228) *\end{array}$ \\
\hline C.A. & + & 0 & 102 & $\begin{array}{l}14.1 \\
(12.7) *\end{array}$ & $\begin{array}{l}108 \\
(112) *\end{array}$ \\
\hline W.D. & + & & 119 & $\begin{array}{l}9.4 \\
(9.4) *\end{array}$ & $\begin{array}{l}76.9 \\
(65.8) *\end{array}$ \\
\hline
\end{tabular}

कUrine steroid determinations performed by method of Silber and Porter.

sence of probenecid. This discrepancy suggested a tubular excretory process. It should be noted that tubular excretion of methyl glucuronide, phenyl glucuronide and resorcinyl glucuronide, but not pregnanediol glucuronide, has been demonstrated in the chicken (12). The clearances were repeated following the administration of probenecid and in all except one subject there was a lowering of the 17-OHCS-Gluc clearances in the presence of the drug. The steroid analyses in this case were technically unsatisfactory but have been included for completeness. Probenecid had no effect on the clearance of $17-\mathrm{OHCS}$. This finding is in agreement with that of Gardner, Crigler, and Migeon (13), who observed that the drug did not alter the excretion of unhydrolyzed 11-oxycorticosteroids although 17-ketosteroid excretion was impaired.

\section{DISCUSSION}

The evidence presented indicates that human plasma protein has a high affinity for $17-\mathrm{OH}$ corticosteroids when these steroids are present in physiologic concentrations. The binding is of a loose, freely reversible character. The addition of an organic solvent phase to the dialysis equilibrium system, such as carried out by Axelrod and Zaffaroni (14), results in nearly complete extraction of the corticosteroids from the plasma. Precipitation of proteins with the usual protein precipitants disrupts the steroid-protein union. The nature of the steroid-protein bond is incompletely understood. The participation of the unsaturated ketone at $\mathrm{C} 3$ has been suggested by Westphal (15) on the basis of a decrease in the extinction coefficient and a displacement of the absorption maximum in the ultraviolet region of the spectrum of progesterone in albumin solutions. The decreased binding of the 17-OHCS-Gluc might be due both to the hydrophilic character of the glucuronide component and reduction of the unsaturated ketone.

The binding of $17-\mathrm{OHCS}$ restricts the ready 


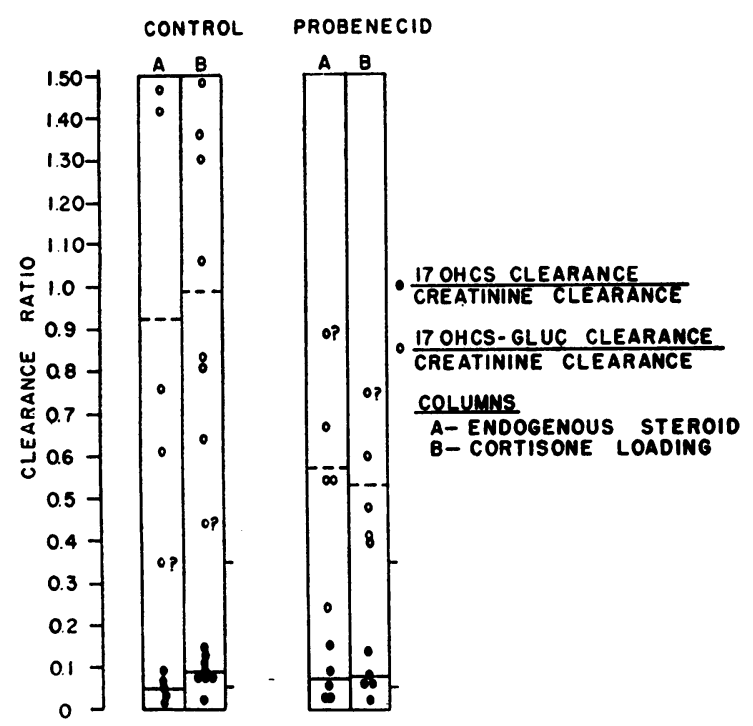

Fig. 2. The Clearance Ratios of 17-OHCS and 17OHCS-Gluc Without Steroid Loading (Column A) AND After the INGESTION OF 75 Mg. OF CoRtisone (COLUmN B)

At a later date the clearances were repeated after probenecid. The tabs to the right of the columns indicate the clearance predicted on the basis of the simple filtration of non-protein bound 17-OHCS (lower tab) and non-protein bound 17-OHCS-Gluc (upper tab).

passage of corticosteroids across capillary membranes. Evidence for this view may be found in the low concentrations of $17-\mathrm{OHCS}$ which have been reported in normal cerebrospinal fluid (16). The higher concentration of 17-OHCS detected in certain transudates and exudates can be attributed to the protein content of these fluids and the affinity of the respective protein elements for corticosteroids. Ascitic fluid has been tested in this laboratory and has demonstrated affinity for corticosteroids only somewhat lower than plasma. The conclusion of Cope, Hurlock, and Sewell (17) that adrenal cortical hormone diffuses freely into ascitic, pleural, amniotic and synovial fluids needs qualification. It would seem more correct to state that the non-protein bound steroid of the plasma diffuses readily into such fluids and the eventual concentration achieved in such fluids is determined in part by the binding affinity of the proteins of the fluid.

The importance of serum albumin in plasma binding of steroids is indicated by this study. Although considerable denaturation of the lipoprotein fractions occurs with lyophilization, there is no evidence in the present results or in electrophoretic studies presented in an accompanying paper (18) that lipoproteins are important in steroid binding. It is of interest that the affinity of human albumin (Fraction V) for hydrocortisone is greater than bovine serum albumin at lower steroid concentrations. This observation is also in accordance with that of Westphal (15), who observed a greater decrease in ultraviolet extinction when progesterone was bound by human albumin as compared with bovine serum albumin.

The increased affinity of Fraction $\mathrm{V}$ for hydrocortisone at low steroid concentrations occurs at steroid to protein molecular ratios far below unity. To explain this behavior it is necessary to postulate that there is a heterogeneity of binding sites either intrinsic or induced by denaturation among albumin molecules, or that the steroid binding sites are partially occupied by other substances in the Fraction V preparations. Although we have demonstrated a high affinity of human Fraction V for hydrocortisone, the degree of binding demonstrable in plasma from patients receiving cortisone exceeds that which can be explained on the basis of the results with Fraction V. In other experiments we have added tracer quantities of hydrocortisone-4-C $\mathrm{C}^{14}$ to plasma of patients receiving hydrocortisone by mouth to determine whether the binding to plasma proteins which occurs in vivo differs from that occurring in vitro. The degree of binding was of the same order of magnitude whether measured radiochemically or chemically. The behavior of human albumin at physiologic hydrocortisone concentrations is being studied further.

\section{SUM MARY}

1. Dialysis equilibrium experiments have been carried out on human plasma obtained 2 hours after the ingestion of oral cortisone acetate. An average of 94 per cent of the $17-\mathrm{OH}$ corticosteroids and 65 per cent of the $17-\mathrm{OH}$ corticosteroid glucuronides were loosely bound to plasma proteins.

2. Human plasma Fraction $\mathrm{V}$ and to a lesser extent Fraction IV-4 possessed significant steroid binding activity. The binding observed in Fraction IV -4 could be attributed to its contained albumin. 
3. The binding affinity of human Fraction $\mathrm{V}$ increased as the concentration of hydrocortisone decreased. This behavior was not noted in bovine serum albumin.

4. The low renal clearance of $17-\mathrm{OH}$ corticosteroids after cortisone acetate ingestion can be related to low concentration of non-protein bound steroid available for filtration. The clearance of $17-\mathrm{OH}$ corticosteroid glucuronides is higher than can be explained by simple filtration of the nonprotein bound component. This observation plus the depression of the clearance of the glucuronide fraction with probenecid suggest a tubular excretory process.

\section{REFERENCES}

1. Daughaday, W. H., and Hartnett, C., Binding of corticosteroids by plasma proteins. Federation Proc., 1956, 15, 238.

2. Bischoff, F., and Katherman, R. E., Solubility of estrone in biologic systems. Federation Proc., 1952, 11, 188.

3. Eik-Nes, K., Schellman, J. A., Lumry, R., and Samuels, L. T., The binding of steroids to protein. I. Solubility determinations. J. Biol. Chem., 1954, 206, 411.

4. Schellman, J. A., Lumry, R., and Samuels, L. T., The binding of uncharged molecules to proteins. II. Testosterone and bovine serum albumin. J. Am. Chem. Soc., 1954, 76, 2808.

5. Krebs, H. A., and Eggleston, L. V., The oxidation of pyruvate in pigeon breast muscle. Biochem. J., 1940, 34, 442.

6. Weichselbaum, T. E., An accurate and rapid method for the determination of proteins in small amounts of blood serum and plasma. Am. J. Clin. Path., 1946, 10, 40.

7. Nelson, D. H., and Samuels, L. T., A method for the determination of 17 hydroxy corticosteroids in blood: 17 hydroxycorticosterone in peripheral circulation. J. Clin. Endocrinol., 1952, 12, 519.

8. Silber, R. H., and Porter, C. C., The determination of 17, 21-dihydroxy-20-ketosteroids in urine and plasma. J. Biol. Chem., 1954, 210, 923.

9. Folin, O., and Wu, H., A system of blood analysis. J. Biol. Chem., 1919, 38, 81.

10. Weichselbaum, T. E., Mendeloff, A. I., Margraf, H. W., and Sheppard, M., Jr., Hepatic conjugation and renal clearance of 17-hydroxycorticosteroids in man. Federation Proc., 1955, 14, 301.

11. Bongiovanni, A. M., and Eberlein, W. R., Determination recovery, identification and renal clearance of conjugated adrenal corticoids in human peripheral blood. Proc. Soc. Exper. Biol. \& Med., 1955, 89, 281.

12. Sperber, I., The excretion of some glucuronic acid derivatives and phenol sulfuric esters in the chicken. Royal Agric. Coll. Sweden, Uppsula. Lantbrugshögskolans Annaler, 1948, 15, 317 (Biological Abstracts, 1949, 23, 2434).

13. Gardner, L. I., Crigler, J. F., and Migeon, C. J., Inhibition of urinary 17-ketosteroid excretion produced by "Benemid." Proc. Soc. Exper. Biol. \& Med., 1951, 78, 460.

14. Axelrod, L. R., and Zaffaroni, A., The extraction of corticosteroids from blood and tissues by dialysis. Arch. Biochem., 1954, 50, 347.

15. Westphal, U., Spectrophotometric demonstration of interaction between proteins and $\Delta^{4}-3$-ketosteroid hormones. Federation Proc., 1956, 15, 382.

16. Sandberg, A. A., Eik-Nes, K., Nelson, D. H., and Tyler, F. H., Levels of 17-hydroxycorticosteroids in body fluids. J. Lab. \& Clin. Med., 1954, 43, 874.

17. Cope, C. L., Hurlock, B., and Sewell, C., The distribution of adrenal cortical hormone in some body fluids. Clin. Sc., 1955, 14, 25.

18. Daughaday, W. H., Binding of corticosteroids by plasma proteins. II. Paper electrophoresis and equilibrium paper electrophoresis. J. Clin. Invest., 1956, 35, 1434. 